Original Research Paper

\title{
Working Time Allocation and Income of Small-Scale Laying Hens in Blitar, Indonesia
}

\author{
Budi Hartono, Puji Akhiroh and Nanang Febrianto \\ Faculty of Animal Science University of Brawijaya, Malang, 65145, Indonesia
}

\author{
Article history \\ Received: 31-05-2021 \\ Revised: 05-08-2021 \\ Accepted: 12-08-2021 \\ Corresponding Author: \\ Puji Akhiroh \\ Faculty of Animal Science \\ University of Brawijaya, \\ Malang, 65145, Indonesia \\ Email: pujiakhiroh@ub.ac.id
}

\begin{abstract}
The purpose of this research was to analyze the working time allocation on laying hen's household and to analyze the laying hens farmer's income in Blitar Regency. Blitar Regency was purposively determined as the research location, with the consideration that Biltar Regency is one of the largest populations of laying hens in Indonesia. The research was conducted from May to September 2020. The results of the research show that the time allocation for farming business is divided into three allocations, firstly time allocation in the household, second time allocation in the farming business and the third is time allocation of additional workers in the farming business. Time allocation in the household was mostly allocated by the wife. Husbands allocate the most time for laying hens farming business. On the other hand, time allocation by additional workers is an allocation of working time for male workers and female workers with a working time duration of 6 to $7 \mathrm{~h} \mathrm{a}$ day. Male workers are more often employed than female workers, this is because male workers can focus more on working and can handle jobs that require physical strength, lifting feed and cleaning up the leftover feed. Some farmers are assisted by their children and parents in running the household and farming business.
\end{abstract}

Keywords: Time Allocation, Laying Hens, Farming, Business

\section{Introduction}

Blitar Regency is one of the centers of livestock production in East Java, especially poultry. In 2019, egg production in Blitar Regency was able to meet $75 \%$ of the egg needs in East Java. There are many egg production centers in Srengat, Ponggok and Kademangan Districts (BPS Kabupaten Blitar, 2019). The livestock sector, in this case laying hens, is an important sector because it contributes to the provision of cheap protein and is much needed by the community. The livestock sector must receive the attention of various parties, including researchers, because good livestock conditions are needed by the region, the country and the world. Blitar Poultry Association data quoted from Poultry Indonesia (2013), of about 3,000 laying hens in Blitar Regency, 70\% of them are small-scale breeders/people's farmers.

The effect of animal husbandry sector for economically side is to encourage economic growth, economic growth can improve human living standards in an area, furthermore economic growth can reduce poverty. The advantage of good laying hens farming conditions is that people will easily get cheap animal protein, immunity will increase so that people will be productive, work and work to advance the country and the world. The disadvantage if the laying hens farming sector is not running well then the condition of an area will also be bad. So that attention to the livestock sector should be increased. Especially laying hens who have a small scale. How do they run a business, share their time in running a business, we even need to look at the income of the livestock business they run.

Small-scale farmers employ family members, both partners and children as a whole, or only work with partners. Some of them also recruit employees to help. The more livestock population, the more employees need. In addition, because employing family members of farmers does not calculate wages for work done alone, this affects the income earned related to lower labor costs. This smallholder livestock business is characterized by relatively little ownership, mostly using family labor and the use of technology is still hereditary. Farmers function as decision makers who try to make effective and efficient decisions in running and managing their livestock business. The role of family members in the livestock business has contributed to the progress of the business 
being run. Contributions in the livestock business are also related to the way farmers manage and the assistance from employees in charge of carrying out activities in the livestock business. Each has its own section, with each a different time allocation. There are farmers who run their businesses full time and some who run part time, so it is necessary to analyze separately how much time is provided by farmers, family members and employees to run their business properly.

The purpose of this study was to examine the time allocation given by farmers breeders, families and employees to do business in the field of animal husbandry. So that it can be obtained an overview of how much time is allocated for each family member and employee on the ranch business that is run. So that will get an overview of the conditions of time allocation both full time and part time. In addition, this study aims to examine the income of farmers, the costs incurred by farmers and the acceptance of small-scale farmers who can provide a further picture of the laying hens farming business on a small scale. In the end, this research can be used as a decision-making material for people who want to enter the business world as well as stakeholders in the field of laying hens in Indonesia.

\section{Materials and Methods}

\section{Location and Time of Research}

The research implementation time, which included data collection, data analysis and report writing, lasted from May to September 2020. The research location was in Blitar Regency, East Java, Indonesia. The determination of Blitar Regency as the research location was carried out purposively, with the consideration that Biltar Regency is one of the districts with the largest population of laying hens in Indonesia.

\section{Sampling Method}

The determination of the minimum number of samples is carried out with the consideration that the samples taken are representative of the population. The number of samples in the study was 166 layer chicken farmers breeders selected by purposive sampling. All sample farmers breeders are members of farmer groups and have had more than 5 (five) years of farming experience. To facilitate descriptive analysis that can describe the actual conditions, the sample is grouped into 3 (three) scales based on livestock ownership, namely scale I (43 respondents with livestock ownership $\leq 5,000$ birds, scale II (Farmers with livestock ownership between 5,000-10,000 birds) as many as 12 respondents and Scale III (farmers with livestock ownership >10,000 birds) as many as 11 respondents.

\section{Data Retrieval Technique}

The types of data collected are primary and secondary data that are related directly or indirectly to the problem and the research objectives to be achieved. Primary data includes the number of livestock ownership owned and cultivated, namely all types of input and output data related to the factors that affect the applied livestock business household economic income.

Secondary data includes various data and information available in documents sourced from government technical agencies and non-governmental organizations at the village, sub-district, district and provincial levels, such as the Animal Husbandry Service, BPS (Badan Pusat Statistik) and various other relevant agencies that will support the course of this research.

\section{Data Analysis Method}

In general, this research uses descriptive analysis. Researchers explain the household income pattern of layer hens, how important non-agricultural income is the source of income in the structure of the total income of small farm households. All explaining empirical data uses descriptive analysis with the addition of simple quantitative data such as frequency distribution Table 1 to 6 . This is used for the case description of empirical data, for example, the author will show what percentage of the farmer's household income comes from agricultural activities and what percentage comes from non-agricultural activities. Besides, the researchers also showed that the types of activities in the agricultural sector are non-source of alternative income for laying hen farmer households.

\section{Results and Discussion}

The allocation of time spent by farmers is divided into three groups, namely based on business scale. The first business scale is for groups with laying hens ownership of less than 5000 birds and the second scale is for livestock ownership of 5000-10000 birds. As for the third scale, namely ownership of more than 10,000 birds.

Livestock also involves workers in running a livestock business. The workforce in the livestock sector consists of male workers and female workers. Furthermore, when viewed from the contribution in running a livestock business, there are differences in the contribution of male and female workers. Male workers play more roles in the field of animal husbandry, this is because livestock business is a job that requires labor so it is better handled by male workers. This is in accordance with the opinion of Lubis et al. (2016) that the number of male workers in the livestock sector is more than the number of female workers. According to Amalo et al. (2012) in farming activities the effectiveness of work is about $5 \mathrm{~h}$ a day and 7 days every week. The allocation of $5 \mathrm{~h}$ a day per day for external workers occurs because many smallholder farmers manage their own businesses with their families, so that only a few hours of labor are needed. In addition, with the increase in tools, machines and innovative cage 
construction, the need for workers will be smaller. This is in accordance with Putri and Ismail (2021) that through current technology there are tools that make it easy to manage livestock products in the form of tools that can sort and count the number of eggs and can send egg data in the form of SMS (Short Message Service), so as to save labor. Meanwhile, according to Handayani and Agustina (2021) the egg marketing process can use social media

Livestock businesses in the Blitar area have received attention from livestock group organizations in each region, this can facilitate coordination from maintenance to product sales. In fact, many grants and cooperation opportunities collected by various stakeholders both at the local level and from the central government as well as abroad are distributed to farmers through livestock group organizations. Periodically, farmers breeders and livestock group organizations hold meetings to update maintenance methods so as to make it easier for farmers, farmer families and workers to carry out livestock business. This is in accordance with the opinion of Permatasari et al. (2021) that livestock groups that sell joint products have good business efficiency. According to Widjastuti et al. (2021) farmers have a good interest in innovating when there are parties who want to teach new innovations.

In the future, it is hoped that livestock machines will develop so that even though they have a large population of laying hens, feeding and taking eggs does not need to use labor. The integrated marketing system allows farmers to sell livestock products from home without the need to find buyers like today. According to Pasaribu (2021), the results of the study show that online media provide a positive impact on the stability of business life during the pandemic.

Male workers in the livestock sector are prioritized because of the work of lifting and moving feed, feeding and even guarding livestock at night from theft and preventing prey from predators. Women workers in the livestock sector are absorbed more in the downstream sector, for example in the process of adding selling value to technology in the form of products, even at the product marketing stage and product retail process. This is in accordance with the opinion of Taek et al. (2021) that generally work in the field of animal husbandry is carried out by men because work in the field of animal husbandry requires a large and strong workforce while women are helpful.

The involvement of family members is quite helpful in running a livestock business. Farmers will involve their spouses and children in their farming business. The laying hens business in Blitar Regency also involves family members, even the children of the farmers who are tasked with being involved in the cage and marketing process. This is in accordance with the opinion of Hendrawati (2018) that livestock businesses often involve families in helping run livestock businesses. According to Rusdiana et al. (2019) the husband is the main worker in the farming business while the wife and children act as additional temporary workers.

Economically, the process of involving families in laying hens can help reduce labor costs, so that farmers can save money and receive more income. While the drawback of this process is that farmers who do all the business processes themselves will find it difficult to concentrate on other things. So that it is not uncommon for farmers who are too busy to be less updated with the latest methods of raising and continue to use old methods, in addition, farmers who are too busy do not have time to get to know new networks both in terms of innovation and marketing information for livestock products. This is in accordance with the opinion of Subhan et al. (2021) that cost variables such as labor are included in the calculation, even though in reality in the field, farmers use labor in the family.

The following are the results of research related to the allocation of time in running a livestock business which is divided into three business scales. Regarding the type of labor allocation, it can be divided into three, namely the allocation within the household, the allocation of livestock and the allocation of labor, both male and female workers. The time allocation of the pair has the lowest value, which is an average of $2.1 \mathrm{~h}$ a day per day to help the laying hens farming business. Meanwhile, girls have the highest average time allocation, which is $3.75 \mathrm{~h}$ a day per day, this is because girls have extra attention to business, especially at the marketing and recording stages, so that the resulting time allocation is quite high. In addition, girls prefer to stay at home so they are more focused on business.

Overall, the contribution of the family is still below the contribution of the workforce, this happens because the interest in continuing the business in the livestock sector has decreased from generation to generation. Currently in the village it is difficult to find young people who want to enter the world of animal husbandry. Young people prefer to migrate to big cities in search of work rather than managing family farms. This is in accordance with Amam (2021) that the participation of the younger generation in the agricultural sector has decreased and the age structure of the agricultural workforce tends to be dominated by older farmers with age $>60$ years. In current conditions that require staying at home alone, it will trigger young people to be creative by working from home, namely in the family-owned livestock business sector.

Based on the table of farmers' income sources, the largest percentage of farmer income was farming carried out by layer chicken farmers, about $82.7 \%$ for scale I, $68.4 \%$ for scale II. and $88.6 \%$ for scale III. According to with opinion of Nussifa et al. (2016) that in the livestock business, the main source of income for farmers is from the livestock business it grow $2.87 \%$ per year. Meanwhile, 
supporting income sources are other sources of income are outside the livestock business. This shows that the livestock business run by farmers is a business that is used as a livelihood for the farmers

Furthermore, explained by Kurniawan et al. (2013) that the livestock business is a business that has high prospects to run because livestock itself can meet the daily needs of the community for livestock products. Commodities produced by laying hens are a very good market prospect because chicken eggs are a commodity that is quite easy to obtain or is a public good, easy to consume, rich in nutrients, such as protein, vitamins A, D, $\mathrm{E}$ and $\mathrm{B}$, phosphorus and zinc and the prices are cheap, making this chicken egg commodity very attractive to the public. This condition is very good for the use of layer hen farmers in Tabanan Regency to further develop layer chicken farms to be more optimal.
Table 1: Involvement of Workers in Farming Business

\begin{tabular}{lllll}
\hline No & Workers & Total & $\begin{array}{l}\text { Percentage } \\
(\%)\end{array}$ & $\begin{array}{l}\text { Allocation } \\
\text { average } \\
\text { (hour) }\end{array}$ \\
\hline 1. & Male & 33 & 71.7 & 6.25 \\
2. & Female & 13 & 28.3 & 6.5 \\
Total & & 46 & 100 & $6-7$ \\
\hline
\end{tabular}

Source: Primary Data (2020)

Table 2: Involvement of spouses and children in farming business

\begin{tabular}{llcll}
\hline No & Workers & Total & $\begin{array}{l}\text { Percentage } \\
(\%)\end{array}$ & $\begin{array}{l}\text { Allocation } \\
\text { average (hour) }\end{array}$ \\
\hline 1. & Spouses & 42 & 70 & 2.1 \\
2. & Sons & 12 & 30 & 2.5 \\
3. & Daughters & 6 & 10 & 3.75 \\
Total & & 60 & 100 & $2-4$ \\
\hline
\end{tabular}

Source: Primary Data (2020)

Table 3: The source income of farmers

\begin{tabular}{|c|c|c|c|c|c|c|c|}
\hline \multirow[b]{2}{*}{ No } & \multirow[b]{2}{*}{ Income source } & \multicolumn{2}{|l|}{ Scale I } & \multicolumn{2}{|l|}{ Scale-II } & \multicolumn{2}{|l|}{ Scale III } \\
\hline & & IDR & $(\%)$ & IDR & $(\%)$ & IDR & $(\%)$ \\
\hline 1 & Agribusiness & 18.829 .680 & 82,7 & 62.550 .392 & 68,4 & 131.474 .831 & 88,6 \\
\hline 2 & Agribusiness Non-Farming & 1.181 .818 & 5,2 & 7.694 .444 & 8,4 & 11.125 .000 & 7,5 \\
\hline 3 & Non-Agribusiness & 2.754 .118 & 12,1 & 21.166 .667 & 23,2 & 5.750 .000 & 3,9 \\
\hline Total & & 22.765 .616 & 100 & 91.411 .503 & 100 & 148.349 .831 & 100 \\
\hline
\end{tabular}

Source: Primary Data (2020)

Table 4: The Expenses of Farmers

\begin{tabular}{|c|c|c|c|c|c|c|c|}
\hline \multirow[b]{2}{*}{ No } & \multirow[b]{2}{*}{ Farmer expenses } & \multicolumn{2}{|l|}{ Scale I } & \multicolumn{2}{|l|}{ Scale-II } & \multicolumn{2}{|l|}{ Scale III } \\
\hline & & IDR & $(\%)$ & IDR & $(\%)$ & IDR & $(\%)$ \\
\hline 1 & Food Basic Needs & 859.302 & 1,3 & 1.108 .333 & 68,4 & 1.290 .909 & 0,3 \\
\hline 2 & Non Food Basic Needs & 49.109 .547 & 72,4 & 122.733 .730 & 8,4 & 348.693 .204 & 72,5 \\
\hline 3 & Non-Basic Needs & 17.822 .313 & 26,3 & 61.609 .836 & 23,2 & 131.215 .740 & 27,2 \\
\hline Tota & & 67.791 .162 & 100 & 185.451 .899 & 100 & 481.199 .853 & 100 \\
\hline
\end{tabular}

Source: Primary Data (2020)

Table 5: Component of cost

\begin{tabular}{|c|c|c|c|c|c|c|c|}
\hline \multirow[b]{2}{*}{ No } & \multirow[b]{2}{*}{ Component of cost } & \multicolumn{2}{|l|}{ Scale I } & \multicolumn{2}{|l|}{ Scale-II } & \multicolumn{2}{|l|}{ Scale III } \\
\hline & & IDR & $(\%)$ & IDR & $(\%)$ & IDR & $(\%)$ \\
\hline$\overline{1}$ & Fix Cost & 2.125 .780 & 4,4 & 7.271 .572 & 6 & 20.902 .126 & 6 \\
\hline 2 & Variable Cost & 45.783 .354 & 95,6 & 113.706 .325 & 94 & 324.777 .441 & 94 \\
\hline Total & & 47.909 .134 & 100 & 120.977 .897 & 100 & 345.679 .567 & 100 \\
\hline
\end{tabular}

Source: Primary Data (2020)

Table 6: Farmers revenue

\begin{tabular}{lllllll}
\hline & & Scale I & & Scale-II & & Scale III \\
No & Farmers revenue & IDR & $(\%)$ & IDR & $(\%)$ & IDR \\
\hline 1 & Eggs & 62.394 .977 & 93,6 & 173.407 .625 & 94,5 & 445.800 .000 \\
2 & Culled Chicken & 4.130 .595 & 6,2 & 9.840 .272 & 5,3 & 30.694 .650 \\
3 & Chicken Manure & 77.350 & 0,1 & 91.111 & 0,04 & 249.479 \\
4 & Sacks & 64.930 & 0,1 & 212.058 & 0,16 & 478.309 \\
Total & & 66.667 .852 & 100 & 183.551 .066 & 100 & 477.222 .438 \\
\hline
\end{tabular}

Source: Primary Data (2020) 
In addition to having an income, farmers in a living will also spend some funds both to meet their basic needs to buy food as well as other basic needs besides food. Other basic needs besides food, for example, are paying for electricity, water, pulses, cigarettes, etc. Apart from basic needs, farmers also spend money to meet their secondary needs. The following is a table related to the farmer's average expenditure which has been divided based on the three business scales undertaken by the farmer.

Based on the table, the highest expenditure for laying hens is the non-food basic need of $72.4 \%$ for scale I, $66.2 \%$ for scale II and $72.5 \%$ for scale III. Other expenditures that have the second-largest percentage are a non-food basic need, about $26.3 \%$ for scale I, $33.2 \%$ for scale II and $27.2 \%$ for scale III. Meanwhile, the expenditure from farmers who had the least percentage was food basic needs, about $1.3 \%$ for scale I, $0.6 \%$ for scale II and $0.3 \%$ for scale III. This is following the opinion of Kiptia (2018). Consuming activities are activities that must be carried out to meet needs and cannot be negotiated, especially for food basic needs.

Farmers in conducting livestock business must pay attention to the costs that arise, namely fixed costs and variable costs, here is a table of the average cost components of layer chicken farming in Blitar Regency.

Based on the table, the largest costs borne by farmers are variable costs. Variable costs are respectively $95.6 \%$ on scale I, $94 \%$ on scale II and $94 \%$ on scale III. Variable costs consist of purchasing layers, feed, medicines, vaccines, vitamins, electricity, LPG, husks, transportation taxes and communications. Meanwhile, variable costs have each percentage of $4.4 \%$ on scale I, $6 \%$ on scale II and $6 \%$ on scale III. Fixed costs consist of the cost of housing, land rent, equipment and labor costs. According to the opinion of Maulana et al. (2018) Variable costs are the largest expenses compared to fixed costs. Further explained by Wijayanto et al. (2014) that the contribution of fixed costs to all production costs is as much as $0.7 \%$, which means that fixed costs are less compared to variable cost expenses. Meanwhile, the contribution of variable cost to all production costs about $99.3 \%$.

Revenue from the livestock business consisted of several sources of income. The main source of acceptance is eggs as an absolute yield. Apart from eggs, several sources of income also had a good contribution to the main revenue from the laying hens business. Other sources of income from the laying hens business are the sales of culled chickens, the sale of chicken manure and the sale of chicken feed sacks. The following will explain the average acceptance of farmers in running a laying hen business. Based on data laying hen farmers in the Blitar Regency, the main results by egg sales, about $93.6 \%$ on scale I, $94.5 \%$ on scale II and $93.4 \%$ on scale III. The revenue that had the next contribution was the sale of culled chickens, respectively $6.2 \%$ on scale I, $5.3 \%$ on scale II and $6.4 \%$ on scale III. The names that come from feces are $0.1 \%$ on scale I, $0.04 \%$ on scale II and $0.1 \%$ on scale III, respectively. Revenue from the sale of sacks has contributed $0.1 \%$ on the scale I, $0.16 \%$ on scale II and $0.1 \%$ on scale III. As explained by Maulana et al. (2018) that livestock business revenue, apart from selling products, also comes from other aspects such as the sale of manure and sacks.

\section{Conclusion}

The allocation of time for labor in assisting the livestock business is 6-7 h, while the time allocation for labor is 2-3.75 h a day per day. Girls allocate more time than boys. Most of the workers involved in the livestock business are male workers because working in the livestock business requires physical labor. Farmers involve their spouse and children in running the farming business. Businesses that have the highest allocation are on a small scale II.

The highest source of income comes from laying hens agribusiness in Blitar Regency, the highest income is from livestock. The biggest expenditure of farmers is for basic non-food needs. The biggest cost component is production costs, especially feed costs, which tend to increase from time to time. Farmer's income from selling eggs. Currently sales can be made online.

\section{Acknowledgement}

By the Grants Program Research Professor which provide us to achieve research funds for this study, we would like to thank University of Brawijaya.

\section{Author's Contributions}

Budi Hartono: Conception and design, data analysis, article draft, reviewing the article, revised and final submission.

Puji Akhiroh: Data collection, surveyor, input data, tabulation data and analysis data.

Nanang Febrianto: Surveyor data collection, input data and analysis data

\section{Ethics}

The authors declare that the are no issue against this study after publication. 


\section{References}

Amalo, S., Hartono, B., \& Utami, H. D. (2012). Simulation model of increasing rowdy pattern cows on labor outpouring: A case study in South Amanuban District, East Nusa Tenggara Province. Animal Science: Journal of Animal Science Research, https://jurnal.uns.ac.id/Sains-

Peternakan/article/view/4832

Amam, A. (2021). Gaduhan: Sistem Kemitraan Usaha Peternakan Sapi Potong Rakyat di Pulau Jawa. Jurnal Peternakan Sriwijaya, 10(1), 16-28. https://ejournal.unsri.ac.id/index.php/peternakan/arti cle/view/13030

BPS Kabupaten Blitar. (2019). Egg Production of Blitar Regency 2019. https://blitarkab.bps.go.id/

Handayani, N., \& Agustina, N. F. (2021, February). Pengembangan Industri Kecil Menengah (IKM) melalui Digital Market (Studi Kasus pada Industri Pembuat Tahu dan Peternak Ayam Bertelur). In Prosiding Seminar Nasional Pengabdian Masyarakat LPPM UMJ (Vol. 1, No. 1). https://jurnal.umj.ac.id/index.php/semnaskat/articl e/view/8003

Hendrawati, I. G. A. O. (2018). Cur\#ahan tenaga kerja peternak sapi bali sebagai usaha sampingan dan dampaknya terhadap pendapatan keluarga di kecamatan penebel, kabupaten tabanan. dwijenAGRO, 8(1), 63-72.

http://ejournal.undwi.ac.id/index.php/dwijenagro/arti cle/view/652

Kiptia, A. (2018). Pengaruh pendapatan perkapita dan harga kebutuhan pokok terhadap tingkat konsumsi masyarakat di tulungagung tahun 2014-2015. http://repo.iain-tulungagung.ac.id/7548/

Kurniawan, M. F. T., Darmawan, D. P., \& Astiti, N. S. (2013). Strategi pengembangan agribisnis peternakan ayam petelur di Kabupaten Tabanan. Jurnal Manajemen Agribisnis, 1(2), 53-66.

Lubis, Y. H., Firman, A., \& Arief, H. (2016). Analisis Curahan Tenaga Kerja Dan Pendapatan Keluarga Peternak Sapi Perah. Analysis of Worktime Allocation and Family Income of Dairy Farmers. Universitas Padjadjaran. Bandung.

http://journal.unpad.ac.id/ejournal/article/view/10 268

Maulana, F. H., Prasetyo, E., \& Sarengat, W. (2018). Analisis Pendapatan Usaha Peternakan Ayam Petelur Sumur Banger Farm Kecamatan Tersono Kabupaten Batang. Mediagro, 13(2).

https://www.publikasiilmiah.unwahas.ac.id/index.ph p/Mediagro/article/view/2155
Nussifa, N., W. Roessali \& H. Setyawan. 2016. Analisis Pendapatan pada usaha ayam petelur "Suyatno Farm" di desa kalisidi kecamatan ungaran barat, kabupaten semarang.

http://jurnal.polbangtanyoma.ac.id/index.php/jp3/arti cle/view/108/102

Pasaribu, R. (2021). Optimalisasi media online sebagai solusi promosi pemasaran umkm di semarang pada masa pandemi covid-19. Jurnal Komunikasi dan Media, 1(1), 33-44. http://103.243.177.137/index.php/jkm/article/view/2 848

Permatasari, D. A., Koesnoto, S., \& Widya, P. L. (2021). Cost Efficiency of Lay Duck Farming in Candi Sidoarjo. http://doi:10.20473/mkh.v32i2.2021.79-89 https://www.ejournal.unair.ac.id/MKH/article/view/2 6640

Putri, D., Ismail, S. J. I., \& Sularsa, A. (2021). Alat Penyortir Dan Penghitung Jumlah Telur Pada Kandang Peternakan Ayam Petelur. eProceedings of Applied Science, 6(3).

https://openlibrarypublications.telkomuniversity.ac.id/in dex.php/appliedscience/article/viewFile/13923/13663

Rusdiana, S., Adiati, U., Hapsari, A. A. R., \& Kusumaningrum, D. A. (2019). Financial Analysis Of Dairy Cow Business With Way For Results (Half) In Farmers. Balai Penelitian Ternak Ciawi. Bogor. Journal of Economic, Public and Accounting (JEPA) ISSN Online 2623-2472 Vol. 2 No.1 Oktober 2019, $\mathrm{H}, 67-85$. https://ojs.unsulbar.ac.id/index.php/jepa/article/view/ 453

Subhan, S., Syahadatina, R., \& Usman, U. (2021). Menilai kelayakan usaha bagi peternak ayam petelur. ngabdimas: unira, 1(1), 9-15.

http://ejournal.unira.ac.id/index.php/ngabdimas_unir a/article/view/1064

Taek, T. S., Lole, U. R., \& Keban, A. (2021). Analisis Kelayakan Usaha Ternak Sapi Potong di Kecamatan Raimanuk Kabupaten Belu. Jurnal Nukleus Peternakan, 8(1), 14-22.

http://ejurnal.undana.ac.id/nukleus/article/view/4222

Widjastuti, T., Setiawan, I., Wiwin, T., \& Gandira, D. (2021). Usaha Ternak Ayam Sentul melalui Optimalisasi Pemanfaatan Feed Additive Herbal di Kelompok Tani Ranca Bawang 1. Jurnal Aplikasi Ipteks untuk Masyarakat. ISSN-10: 1410-5675.

Wijayanto, N., Fanani, Z., \& Nugroho, A. B. (2014). Analisis kinerja finansial peternakan broiler antara pola kemitraan dan pola mandiri (studi kasus di Kabupaten Jombang). Jurnal Peternakan. https://www.academia.edu/download/35522291/anal isis-kinerja-finansial-peternakan1.pdf 